\title{
Medieval Manila: Life at the Dawn of the 20th Century
}

Jason A. de las Alas

\section{ABSTRACT}

The Spanish established the city of Manila upon similar principles used to found medieval European cities. However, Manila by the dawn of the $20^{\text {th }}$ century was already an antiquated and obsolete human settlement. This paper depicts the crude life people endured inside the city, comparable to conditions in the medieval cities of Western Europe centuries before. It will establish that Manila was underdeveloped and poorly maintained despite three centuries of Spanish rule. This paper explores the life both of the elite and of the ordinary resident of the Walled City, focusing on the aspects of house design, the social graces, urban problems, transportation, and communication.

KEYWORDS: Manila, City Planning and Living, Urban Development

\section{Introduction}

The old city of Manila was the center of colonial rule in the Philippine archipelago at the beginning of the $20^{\text {th }}$ century. The Spanish domination that lasted three hundred years was coming to a close and a new, much younger nation was taking the place of the weakened European colonizer. Spain was not the global empire that it was centuries before (Hahn 27). Spanish Manila, founded as a colonial settlement, had served as the center of governance and culture in the colony. Despite the changing times, it maintained its character and nature, which were both European and native at the same time. In the feudal era, a town or a city provided its inhabitants with employment as well as everything else they needed (Pounds 1). This was the purpose that Manila served, and the reason that it grew and endured. 
The city of Manila, i.e. the Walled City or Intramuros, was hardly "modern" according to the standards then. For a Southeast Asian city that was strategically situated and was growing in importance for the new Western powers, Manila remained feudal in character. The old center of Manila had many characteristics of a city that could have been built in antiquity. Life inside the walls was crude, harsh, and barely comfortable compared to present-day city life. Despite these conditions, the residents inside Old Manila or Intramuros were able to maintain a culture that reflected the long years of Spanish influence.

\section{The Beginnings of Manila}

Long before the arrival of Spanish conquistadors in the $16^{\text {th }}$ century, Manila had already been a small settlement for the Tagalog people. It did not simply become a large European-type city out of nowhere. The terrain was a suitable location given that its natural resources could sustain a large community. The land was situated on a strategic position at the mouth of the Pasig River and the banks of Manila Bay, which made water accessible. A nascent village could thrive and expand into a metropolis given the large tracts of land surrounding the settlement.

When the Spanish colonizers arrived, Manila was headed by the local chieftain, or datu, in the person of Raha Sulayman. According to Patanñe, Manila was a fortress-settlement commanding the mouth of the Pasig River. The area of the settlement facing the wide beachhead of the bay was marked by a wooden palisade."1 But the settlement even then was already trading with the outside world. When the conquistador Miguel Lopez de Legaspi's aide, Martin de Goiti, arrived to conquer the settlement in Manila, he found forty Chinese residents inside (Patanñe 9, 11). The Tagalog settlement had acquired a reputation as a wealthy trading center by the time of China's Ming dynasty (Patanñe 10). That was part of the reason why a potential colonizer

${ }^{1}$ The land of Manila is situated on a delta. It was formed by sediments from the Pasig River and sand and mud from Manila Bay. It was very difficult to enter the delta because of a sandbar. Antonio de Morga claimed that this sandbar was hardly fit to anchor larger vessels. Small ships could enter the Pasig River but they had to be light or had to have their cargo unloaded before entry into the Pasig. (Patanñe 11) 
would consider Manila to be a strategic location for establishing a foothold on the Asian continent.

The Spanish invaders found the Tagalog settlement to be well-situated as well as highly fortified. De Riguel, a notary with the de Goiti expedition described the settlement and its defenses:

[It is] situated on the bank of the river, and seemed to be defended by a palisade all along its front. Within it were many warriors, and the shore outside was crowded with people. Pieces of artillery stood at the gates, guarded by bombardiers, linstock in hand. A culverin shot from us, and close to the houses of the natives were four Chinese ships... (Patanñe 11)

It was evident that Manila was geographically an ideal place upon which to establish the center of Spanish presence in the Philippine archipelago. The Spanish conquerors thus built on the success of the local community that had already been thriving there. And so it was that the the Spanish built the Walled City of Manila or Intramuros to become the colonial capital city.

The Spanish built their new city following the outline already established by the pre-existing settlement. In the medieval era a city had to provide for both the needs and the protection of its inhabitants (Pounds 1-55). Manila was able to meet these needs. The Spanish erected Fort Santiago on the area of the Tagalog settlement that was fortified with a palisade (Patanñe 11). The position of the fort guarded the entrance to the Pasig River, which served as an excellent commercial passageway. ${ }^{2}$ The city grew to become the "political, cultural, educational, religious, and commercial center of Spain's Empire in Asia" (Torres 6). All things centered on the interior of the city as Spain established its presence in this region of the globe.

Manila also served as a portal to the rich natural resources of the main island of Luzon, which was abundant with quantities of gold, hard tropical wood, and undetermined amounts of silver, mercury, iron, copper, lead, brown coal, petroleum, and true coal (Hamm 19). However, the Spanish coloniz-

${ }^{2}$ According to Patanne, "The region that was Manila Bay and Laguna de Bay by the time of the Ming emperors had already acquired a reputation as a potentially rich trading area" (10). 
ers were not able to fully explore and make use of the wealth of this land to develop the rest of the territory. Margherita Arlina Hamm, writing late in the $19^{\text {th }}$ century, spoke of the archipelago's abundance: "Of its resources but little is thoroughly known. Spanish policy has been discouraging all enterprise by native as well as foreigner, and the territory of today is the same as it was a century ago, so far as investigation and exploitation are concerned" (19). In addition, the global Spanish Empire itself was collapsing and was losing land and subjects. According to Chandler et al., "[t]he decades of war in Europe weakened Spain, diverting attention and resources from colonial development projects" (149). The Spanish government in the Iberian Peninsula was in turmoil in the $19^{\text {th }}$ century. Because of the rapid changes in the Spanish system of government, the overseas territory of the Philippines was left with no stable political base. The Spanish authorities also neglected economic development in the Philippines (Hahn 27). Thus, under Spanish dominion, Manila never developed to become a modern, independent, self-sustaining and efficient territory. The Walled City remained a monument of the conquest of the archipelago centuries before. It existed as a human settlement but did not develop into a space for modern urban life.

\section{City Planning and Development around the Walls}

The name "Intramuros" literally defines the city of Manila as an area surrounded by stone walls; this was typical of classical and medieval cities in Europe at the time the city was founded. The term "Manila" itself had three meanings. The first and legal meaning was the Walled City. The second and more popular meaning was the Walled City and its suburbs. However, a few would refer to Manila as a province, district or county of Luzon (Hamm 26). This study of Manila's feudal history and character, however, will revolve around the original, enclosed Walled City and the surrounding land.

The Spanish established the city of Manila based on the city plan and layout of European cities and of their territories in the Americas. Cities were planned in one of two ways: either as an inland or as a coastal urban center. Using the inland plan, the plaza mayor served as the physical center of the city; the coastal plan placed the plaza near a body of water. Manila and the other colonial towns in the archipelago followed the latter design (Javellana 34-35). This was practical as the settlements needed access to waterways to sustain 
themselves. Even in Europe, major cities developed along rivers (Nicholas 63). Also important was the location of the government center at the city central plaza (Torres 4, 6).

Spanish Manila was built based on the urbanization ordinances of 1573 under Philip II of Spain. The main theme of this standard design was the "interplay of open and built spaces laid following a grid" (Javellana 34). Open plazas were located in front of public edifices and were intended for large crowds to gather in (Javellana 34). The road system followed a grid pattern that, according to Javellana, "delineated the city block. The principal street, the widest and the most beautiful lead to and from the plaza mayor and connected the urban space with the rest of the network of roads linking a district" (Javellana 34). The main road inside the Walled City was named Calle Real, meaning the "royal road." In the grid plan, secondary roads were parallel to the primary arteries. Inside the walls, the city was divided into sixty-four blocks and four barrios: San Antonio, San Carlos, San Gabriel, and San Luis (Javellana 34). The Walled City followed the European pattern of streets of various sizes and also featured large areas, markets, and squares (Nicholas 62).

The government of Manila as well as of the whole archipelago centered on the city's main square. This administrative epicenter reflected the control both the government and the Roman Catholic Church had on the lives of the people. The Spanish governor-general resided in the Palacio del Gobernador, while the Spanish Archbishop of Manila had the Palacio Arzobispal. ${ }^{3}$ Across the governor's residence, the City Council or Cabildo held office inside the Ayuntamiento or Casas Consisterioles (Torres 6).

The walls of the colonial city were intended to protect the Spanish residents inside against foreign invaders and pirates. The walls were two and a quarter miles long and ten to twenty feet thick (Hamm 27). Watchtowers and bastions lined the walls, while a shallow moat surrounded the periphery. The latter actually proved to be a health hazard to residents. Nine bastions or baluarte lined the stretch of the wall: San Miguel, Medio San Francisco, San Francisco Javier, Plano Luneta de Santa Isabel, San Diego, San Andres, San

${ }^{3}$ The Palacio del Gobernador was the official residence of the head of the colony until 1863, when the residence was moved to Malacañang. (Torres 6) 
Francisco de Dilao, San Gabriel, and Santo Domingo. There were also seven access gates, namely, the Postigo, Sta. Lucia, Real, Parian, Isabela II, Sto. Domingo, and Almacenes. ${ }^{4}$ These gates were closely guarded to regulate the movement of people. Until the 1890s, these gates were closed by midnight and only opened by dawn (Torres 1).

Beyond aesthetic value and the sense of security, the walls provided little actual protection for the people of Manila. The last time the walls were tested in actual combat and suffered an exchange of fire was during the British invasion in the $18^{\text {th }}$ century, when Spain had to give up the city to the new attackers. The fortifications however provided little protection against newer methods of warfare (Hamm 26-27). The defensive structures of Intramuros did not sufficiently develop to match advancements in weaponry and military tactics.

The medieval style of defenses was obviously already obsolete by the $20^{\text {th }}$ century. The wall emplacements of Intramuros included cannons from the $15^{\text {th }}$ century as well as some from the current period. These cannons did not have significant firepower and were no match against the artillery of modern warships plying the bay or of siege batteries on land (Hamm 27). The stronger firepower and better range of the latter could overwhelm the obsolete city defenses enabling enemy troops to overrun the entire city.

By the entry of the $20^{\text {th }}$ century, Manila had expanded beyond the medieval walls and into the suburbs. With the surrounding terrain of Intramuros slowly filling up due to expanding human habitation, the city's walls and defenses soon lost their use and value. The walls also had a detrimental effect on human settlements: these structures restricted the entry of goods and services into the city (Nicholas 29). Because of the growth of residential areas on the suburbs, the protection provided by the massive defensive structure was no longer important for most of the inhabitants of Manila. The walls, though, remained as insurance for the people residing inside the city. The structure was also a matter of pride for the citizens: it was featured on the city heraldry (Pounds 29-30). But in the end the limited area inside Intramuros could no longer accommodate the ever-growing, diverse population of Manila.

${ }^{4}$ The Sto. Domingo and Almacenes gates were demolished during the American Period. (Torres 1-2) 


\section{Spiritual Life}

Religion played an essential part in the residents' daily life. The Catholic faith featured many traditional religious activities that were practiced by the baptized peoples of the colony. Robert MacMicking, an English traveler in Manila, recalled:

The military band usually performs before the palace on Sunday and feast evenings. On these events, carriages go from the drive at about 8:00 p.m. to enjoy the music. People also take time for gossip and love making.

Religious processions are as frequently passing through the streets, as they are in all Catholic countries of Europe but the features are all very nearly identical. When one of these processions takes place during the day, an awning is spread along the streets it will pass through, to protect the bareheaded promenaders from the sun, the canvas being attached to the houses' roofs along the streets. (23)

Religion formed the culture of the residents inside the old city as well as those who resided in its suburbs. The big number of churches and the variety of religious orders answered the spiritual needs of the Catholic population. As the colonial capital, the Walled City served as the center of religion in the same manner as feudal cities served as home to religious orders and as centers that responded to spiritual needs (Nicholas 8).

The religious orders arrived at different years following the establishment of Spanish Manila under Legazpi. The priestly orders and their year of arrival were as follows: Augustinians (1571), Franciscans (1578), Jesuits (1581), Dominicans (1587), Augustinian Recollects (1606), Hospitallers of God (1641), and Franciscan Capuchins (1886). Various orders erected several churches in Manila, including the Manila Cathedral, and the churches of San Agustin, Lourdes, San Ignacio, San Francisco, Santo Domingo, and Recoletos. These large edifices dominated the city skyline. The religious orders also owned and administered educational institutions (Torres 2, 7). 
However, the Spanish colonial government never asserted its authority over the religious orders. The governor-general had little influence over the activities of the friars. Many of the religious orders actually possessed lands in the archipelago. According to Chandler et al., priests had the privilege of an "independent structure of accountability" (150). This meant that the religious orders could easily evade punishment for abuses inflicted on inhabitants of the archipelago, especially on the native Filipinos.

\section{Business Inside and Outside}

At the end of the $19^{\text {th }}$ century much of the commercial activities in Manila occurred outside the Walled City, in the less-congested suburbs. The needs, not only of those inside the fortress-city, but also of the greater populace had to be met. The Walled City itself could not be sustained without the industries and commercial enterprises operating in the surrounding suburbs.

Business centered outside the old city in areas such as Binondo. This place served as the business quarter of the greater Manila area: it was beyond the original Spanish city and was situated directly across the Pasig River (Howard 28). This river served as the major waterway for merchants coming in via Manila Bay. In addition to Binondo, Escolta and Rosario were also active business districts (MacMicking 20). These places were all located outside, since the walls of the city made it difficult to engage in trade in the interior. The surrounding land adjacent to the waterways of Manila Bay and the Pasig River efficiently served their appropriate purpose for the old city.

It was only at the dawn of the $20^{\text {th }}$ century that Manila became aggressively expanded its foreign commerce. The government realized that free trade and foreign commercial investments were imperative for the survival of the colony, that is must go beyond Spanish commercial self-interests. Chandler et al. explained that "[m]ercantilist exclusion, no longer seen as a visible economic policy by Spain, was succeeded during the course of the nineteenth century by relative freedom of trade and foreign commercial investment. By 1879, the Philippines would be described as 'an Anglo-Chinese colony with a Spanish flag"' (152). The colony expanded its ventures and was no longer reliant on local agriculture as its economic base. The colony had become an 
export economy based on agriculture, particularly on small land holdings (Chandler, et al 152).

Traveler Charles B. Howard recalled the sight of goods at port, that there were "big hemp-presses and hundreds of Chinese coolies trotting up and down, laden with boles of hemp and bags of raw sugar, ready to be sent out to the ships of all nations, lying at anchor one mile from the shore" (28). The Chinese in Manila had been known to be hardworking, aggressive businessmen for centuries. They performed much of the daily hard work in the city (Hamm 29). MacMicking comments that, "Chinamen, as a general rule," were "honest and trustworthy," but supposedly, "only so long as it appears to be their own interest to remain so" (19). The Chinese imported large amounts of goods from the British:

Some of them frequently making monthly purchases to the extent of ten or fifteen thousand dollars from one person, nearly all of the goods being sold to them on delivery of the merchandise. Occasionally, however, some of them break down, and those importers who have been trusting them for large amounts, of course burn their fingers. (MacMicking 19)

Thus did the persevering ancestors of the present Filipino-Chinese business practitioners begin their long and successful trading legacy in the old city.

There were Chinese shops all over Manila that sold various commodities. MacMicking described the shops of the Chinese businessmen as buzzing with activity:

The owner usually engages all the activities of his countrymen employed by him in them, by giving each of them a share in the profits of the concern or in fact making them small partners in the business, of which he of course takes care to regain the lion's share, so that while doing good for him by managing it well, they are also benefiting themselves. (19)

Among the different industries that the Chinese controlled were boot and shoe making, furniture-making, cabinetwork, blacksmithing, iron casting, 
metal smithery, tin-working, tanning, and dyeing (Hamm 29). The Chinese entrepreneur's bottom line was to earn money, no matter how large or small the income was. It was with this business philosophy that the Chinese supplied Manila's residents the goods they needed to sustain themselves inside the cramped Walled City and in the bursting suburbs.

Another large group of merchants that further opened the archipelago to the outside world was the British. These foreign, Western merchants conducted business in dollars or pounds, since they did not accept the peso as trading currency (Chandler, et al 152). Various crops were exported abroad. Manila had to break away from the identity of an isolated, enclosed medieval settlement. Chandler et al. pictured the setting:

As Manila and other ports opened to international commerce, British merchants dominated the import market of textiles, machinery and other finished goods. For a few decades before 1870, the archipelago had in good years exported rice, primarily to China, but as land was shifted into sugar, copra, hemp, or tobacco, the Philippines became a chronic importer of rice. (153)

The export economic activities of the archipelago, however, did not benefit the common man. Land was assessed according to its monetary worth and not according to the crops grown there. Though the lives of peasants changed as they moved towards tenantry and away from the traditional ways of life (Chandler, et al 153), the ordinary Filipino still did not benefit from the economics of the period because of the orientation and development of the archipelago. Manila sustained itself through the venturing spirit of foreign businessmen, not through the Spanish that ruled the archipelago for centuries.

\section{Manila Houses: Structure}

The various houses in the city of Manila were designed and constructed using materials available in the archipelago. Some other factors that had to be considered were the local climate and the inconvenient cramped spaces of the city. But the inhabitants managed to live inside the Walls and even tailored a lifestyle uniquely suited to a tropical Asian home. 
The typical Old Manila house possessed features inspired by both Asian and European styles. Conventional houses had two floors, divided into the habitable and uninhabitable areas. The ground floor was not for habitation: its white-washed stone-and-lime walls were bereft of windows (MacMicking 23). Similar to medieval European homes, cut stones were also used to construct the foundations of houses in Manila. Sometimes an opening was cut into the walls of these houses in order to set up shops for selling rice, fruit, oil, and other goods. This arrangement, however, proved to be inefficient (MacMicking 20): it was not comfortable to live on the second level of a house located inside a congested city with busy, narrow streets down below.

Given the warm climate, ventilation was a crucial factor in building a house in an old, congested settlement like Manila. Large houses were constructed with much allowance for ventilation (MacMicking 20). Still, most of these attempts at architectural design were unsuccessful for the Manila climate. The interior was seldom laid out properly, leading MacMicking to comment that house design was still "deficient in many respects" (20).

The houses in Manila were not all alike. Like a medieval city in Europe, most of the affluent and influential lived in the more desirable block sections of Manila and its suburbs. Any city resident would naturally prefer to live in less crowded and noisy quarters in order to enjoy one's home, especially after a long day. According to MacMicking, the European population of Manila resided "either in the city, principal part of the town outside the walls, [or on] the other side of the river from the city" (MacMicking 20). Those who resided within the walls were mainly Spanish officials and government servants; they lived close to their civil workplace (MacMicking 21). A number of these intramural residents rented houses. Given the intolerable climate and atmosphere of the Walled City, the house owners lowered the rates of the tenants to keep them from leaving (MacMicking 21). Landowners had to find ways to make people stay and live inside the apparently crude city.

It was easy to identify the social status of the occupant based on house design and features. The large European-style houses were spacious inside and were built using a common plan. Most of the houses were quadrangle in shape and enclosed an open courtyard. Usually, stables and coaches were kept inside the ground floor of the quadrangle (MacMicking 21-22). This was also an attempt to maximize the limited plot space of houses inside the city. 
It was the upper level of every house that served as the center of domestic life. People for the most part lived in the upper floor; the space in the ground floor was thought to be uninhabitable. This area was therefore often used as commercial shops during the day or as warehouses for goods or consumables. In order to ensure the structural stability of the house the masonry of the lower walls was constructed to be earthquake-proof while the upper level's wooden structure was fixed with bolts (MacMicking 21). Several huge posts, the size of ship masts, supported the house from the foundation up to the roof. In addition, the windowpanes were made of oyster shells and not of glass. Plaster was also used for wall decoration (Howard 21-2). The windows were framed and arranged in overlapping panels and could be pushed back into the wall to allow the main room to become a veranda (Howard 22).

Nevertheless the houses of the native Filipinos, or indios to the Spanish, were not as elegant and as well-crafted as their masters'. They had to make do with available materials. According to MacMicking, "the houses of the Indian and mestizo population are for the most part in the outskirts of the business part of the town, those of the richer sort being built of stone, and those of the poorest clans being composed of nipa or altap" (Howard 23). In many ways, this served as an allusion to a medieval European world where landlords and nobles lived in grand houses while the mercantile and poorer classes lived in smaller houses on the edges and outskirts of the city walls. Residential streets were very narrow since these were patterned after the European design (Nicholas 161).

Building materials used inside the Walled City and its suburbs also reflected the natural topography of the islands. Different kinds of lumber were used for specific parts of the house. Volcanic tuff or "adobe" was a popular stone material common in the Tagalog and Kapampangan regions of Luzon. The walls surrounding old Manila were constructed with this material. It is described as "gray as slate, interesting ripple-like feel, much pumice, and little clay. It also absorbed less water" (Zialcita and Tinio 34). In Mexico, however, the term adobe refers to the sun-dried bricks made from clay and straw (34).

Clay tiles were originally used for roofing, as they were in in European and Mexican houses. But at the beginning of the $20^{\text {th }}$ century, Manilans began to prefer galvanized iron sheets. The Spanish colonial government mandated the use of galvanized iron roofing to prevent clay roofing tiles from falling 
on the people on the streets below during earthquakes (Laya and Gatbonton 77). New problems appeared, though: the iron sheets absorbed heat during the day, making the house interior much too warm and inhospitable, created too much glare, and corroded as time passed (Zialcita and Tinio 70). What was originally intended to protect against accident or calamity itself became a daily menace for city living.

\section{Life in Manila and the Prim Social Graces}

Life inside the Walled City was less than ideal given the physical conditions there. Intramuros had tight and narrow areas similar to those found in old European cities. Residents had to improvise to sustain themselves. By the turn of the century, it proved to be impractical to continue with an enclosed, medieval style of city living.

The Manila elite lived in the popular addresses inside the city. Membership in this social class was feudal and antiquated in nature: it centered on the concept of land. According to Chandler et al., "[w]ithin Filipino society, elite status was not determined by caste or lineage but by wealth, of which land ownership was the tangible symbol. To climb higher would require access to modern education and equality in the pulpit, which became the wedge issues this emerging elite demanded" (154). This was the concept of aristocracy in Spanish Manila: it was marked by land dominion and favor with the church.

As was mentioned earlier, life centered on the second floor of the house. A wide sitting room was situated there to accommodate visitors and guests (Howard 21). The interiors of these large houses were luxuriously decorated. According to Laya and Gatbonton, "The best Manila houses followed the latest in European interior decor" (83). The designs and furnishings took their inspiration from different parts of the world: "Velvet and lace curtains, imported furniture, Venetian mirrors and chandeliers, and Chinese porcelain were the rage. Ceilings were painted with flowers and cherubs." ${ }^{5}$ But there was more to Manila than just these opulent home features. House construction

${ }^{5}$ These trends in home interior decorations dated from circa 1898. The varying designs were drawn from historical and geographic source themes. (Laya and Gatbonton 83) 
and design also had to take into consideration the natural elements on the urban location.

Manipulating the climate was a challenge for the residents inside the city. Ventilation and air circulation were menacing concerns. The residents and their servants had to keep the interiors cool by keeping the air circulating in and out of the rooms (Zialcita and Tinio 68). This was not surprising considering most of the houses were so close to each other and the streets were narrow. One should also notice how the iron roofing absorbed heat at high noon.

Intramuros was also medieval in the sense that it lacked proper means of sanitation that resulted in sickness and disease. There were no proper measures to prevent an outbreak. According to Zialcita and Tinio, "Filipinos have always dreaded the ground's dampness and dew, the singaw and the hamog, as agents of sickness. They warned children to stay indoors at dusk when the ground rapidly loses its heat in order not to catch a cold" (68). Big families crowded together in the damp, sweating, tiring atmosphere and congestion inside the city walls.

It was also very difficult to get a good night's rest inside the city. It was common to see lizards moving around upon the walls and ceilings of houses at night (Howard 26). Howard described the experience: "We slept on strips of matting, spread over cane-seated couches, the legs of which rested in bowls of water to prevent visits from centipedes, tarantulas, white ants and other tropical gentry, that cannot be kept out of the houses" (25-6).

It was typical throughout the time of Spanish colonial rule for families to have household helpers or kasambahay to perform housekeeping tasks such as cleaning and cooking. They were compensated very lowly. Howard recalled during his stay in Manila:

Our retinue consisted of about sixteen native servants, including the houseboys, coachmen, grooms, gardeners and general hangers-on. This sounds extravagant, but each man received only eight Mexican dollars a month, out of which he clothed and fed himself, and his family, if he had one. 
After we left for our affairs in the morning, the boys had nothing to do until we returned, except to dust the rooms and keep the floors polished. Their hardest duty was to provide the house with water; which was brought every morning in a hogshead fastened to a handcart, from the public fountain nearly a mile away. (22-23)

Cleaning the house was a full-time occupation in Manila as constant dirt and dust entered one's house. It was not enough to sweep the house once a day. The climate, the general dampness and the ever-present dirt challenged city dwellers constantly.

\section{Social Graces and Leisure}

Life inside the large houses of the elite reflected European tastes that got blended with the milieu of the Walled City. Harsh conditions did not hinder a lifestyle among the higher-class inhabitants. They followed a theme of "urbanidad" that was characterized by "a delicacy in taste, graceful and studied gestures, extreme politeness, a desire for knowledge, artistic accomplishment, stylish attire, knowledge of world history and geography, and a fancy home" (Sta. Maria 12). Philippine arts and culture also developed during this time. The local social milieu was enriched with melodies and lyrics, poetry, theater and culinary arts (Sta. Maria 13).

Music was considered important for one's personal formation. Residents of the city had to master a musical instrument such as the flute, violin, cello, piano, guitar, accordion, or the harp. Popular songs such as those from the zarzuela and the opera were in abundance. Dances such as the waltz, rigodon, habanera, and the polka were also popular (Sta. Maria 13). In addition, ability in a foreign language symbolized higher social status; it was considered a "mark of sophistication," indicating that one individual might have traveled and studied abroad (Sta. Maria 12-13). Hospitality was a warm, inviting feature in every Manila home: both family and guests ate well. A household had to undergo a lot of preparation in order to welcome guests. Exquisite culinary arts such as pickling, preserving, confectionery making, pastry making, bread baking and table setting were mastered at home. Families made the presents they gave their guests (Sta. Maria 12-13). 
Jason A. de las Alas, "Medieval Manila: Life at the Dawn of the 20th Century"

The luxurious elite of Manila craved for European dishes. It was a real challenge to serve French cuisine for visitors, as Sta. Maria explained:

Social status depended on a family's ability to awe guests with unusual presentations: a sweet pepper bell with each fruit stuffed and deep fried while clinging to its branch; an erupting volcano of mashed potatoes and a hidden burner aflame; an engine laden with carabao milk pastilles (pastillas de leche), each in paper wrapper hand cut to bear the name of a guest or a hospital message such as "Amistad" (friendship) or "Recuerdo" (keepsake). $(12-13)$

This was an interesting gesture on the part of residents to spend for their guests at home.

Social life also included receptions and functions at other homes and establishments. One could be invited to events like bailes (dances for formal balls), velades (music and literary programs), testulias (intimate get-togethers at home with music, poetry, and conversation), and bodas (wedding with dancing, speech, and poetry recital) (Sta. Maria 13). Aside from the social graces, there was also time for rest and relaxation. Since the inhabitants of the city valued family life highly, they made sure to have regular get-togethers with relations. Reunions were held on Catholic holy days and regular holidays. According to Sta. Maria, "[g]et-togethers gave members of a household opportunities to share in home arts, music, visual arts, poetry, and declamation. Any eligible man or woman was expected to excel in the refinements associated with urbanidad" (12). City life was actually dominated by set schedules: watches and clocks dictated the daily activities and routines (Sta. Maria 12). There was no time for a refined person to procrastinate or simply do nothing, instead, each day had to be "complete" with activities.

However, life was simpler for the ordinary resident of Manila. They did not normally patronize the theater and the opera house. There was a bull ring in the suburb of Paco, but this did not approximate the exciting bullfights in the Iberian Peninsula. According to Hamm, "[i]n place of the fierce Andalusian [sic] bulls which are bred for ring purposes, they have low spirited and decrepit animals of the Philippines" (31-32). The game that did thrive among the ordinary people was cockfighting, which proved so popular that it became 
a regular source of income for the Spanish government. Taxes were rented out to the highest bidder during a cockfight (Hamm 33). In general, however, there were no places established solely for recreation (Foreman 344).

\section{Old City Risks and Water Supply}

For the centuries that feudalism held sway in Europe, people endured the harsh conditions in cities because living there was their means of improving their trades and lives. Intramuros had its share of residential problems similar to those of European cities built in the feudal manner. These included the lack of water, food and fuel supplies for the entire city populace, diseases, inappropriate sewage disposal, congestion, fire hazards, and poor policing against crime (Pounds 17-18).

Life in Intramuros could also be very difficult in the face of calamities. By the 1900s, the adobe wall had lost all practical value, but the congestion inside left the people vulnerable to earthquakes. When a strong tremor struck, structures were heavily damaged and sometimes even collapsed since they were built so close to each other. MacMicking explained the measure taken by the residents: "On the occurrence of an earthquake, it is usual to run downstairs, and have the protection of the thick lower walls against any accident, such as that of the roof giving away" (21). It was difficult to find protection in such a congested city in times of calamities. One had to devise measures oneself to survive such ordeals.

The Walled City was also vulnerable to fire, which could cause much destruction. The only means to contain a conflagration was to destroy all the structures in its path in order to create a firetrap (MacMicking 23). MacMicking explained the powerful effect of such an outbreak inside the city:

Nearly every season, however, some fires happen among them, and hundreds of families are frequently burned out before its progress can be arrested. This, however, is not anything so calamitous an event for them as such an occurrence would be to the poor of Europe, for the chief cost of a nipa house consists in the labor of erection, after such a misfortune, they are soon replaced by their own personal labour, for whatever their usual trade or oc- 
Jason A. de las Alas, "Medieval Manila: Life at the Dawn of the 20th Century"

cupation may be, nearly all of the Indians are quite capable of constructing the houses for themselves, and often manage to complete them roughly in a few days. (23-24)

Other problems for the inhabitants of Manila included the lack of hygiene and sanitation.

Water was an essential commodity for a warm and dusty city such as Manila; people needed it for drinking, cooking, and bathing, among others. The inhabitants of the archipelago valued personal, bodily hygiene, and thus habitually took a bath everyday. But not all the water sources in the Walled City produced water suitable for drinking and cooking. A household's water supply was usually stored in a tank at the second floor, in a back room; drinking water had to be boiled and filtered first (Howard 23). People did not know then the importance of artesian wells. The main source of water for Manila was the Marikina River, and the supply line from Santolan to Intramuros was used by thousands of people. Thus, if the water was not fit to drink, it could bring much disease (Elliot 187, 202). The Carriedo fountain was installed only in 1884, after the people had already suffered from this pressing problem for so many years (Elliott 202). It was typical for an old feudal city for disease to occur because of contaminated water from various unsafe and untreated sources.

A significant source of health problems was the defensive moat that surrounded the Old City. According to Hamm, "[a] large part of the moats are in a revolting condition, being half filled with a hideous mixture of vegetable matter, stagnant water covered with slime, mud, and the refuse of a large city" (27). Though the moat was a breeding ground for malarial diseases, the Spaniards were afraid to clean it (Hamm 27). Elliott explained that "[t]he Filipinos realized nothing of the importance of sanitation and the Spanish officials paid little attention to such matters" (186). This can be explained by the Spanish practice back home where organic waste was just dumped outside the city and sewage was never treated for decontamination (Nicholas 155-56).

The climate of the archipelago was also a factor that contributed to poor health and sanitation in the city. The alternating heat and moisture allowed mosquitoes and other insects to breed in great numbers and bacteria and parasites to thrive all over Manila throughout the year (Elliott 186, 202). The people did not understand back then what they needed to do and so did 
not change their daily habits. They continued to draw drinking water from streams where they and their work animals bathed, and from shallow, open wells that took in dirty water from the streets and the drainage system. As a result, cholera, plague, malaria, and beriberi killed many people through the years (Elliott 187; Pounds 67-8).

Like many of the old, medieval-age cities of Europe of that era, Manila had no sewerage system. All rubbish, house waste and "night soil" were dumped on the streets and alleys. People ridiculously hoped that pigs and animals would clear these away. Narrow canals or esteros were left uncovered; the waterways of the city were thus crawling with slugs and reeked from the refuse emptied into them (Elliott 187). There was hardly any effort to keep the city clean and the population healthy. There were no laws to assure food quality or require livestock inspection; there was no proper slaughterhouse, for instance. The markets in Manila were all dirty. Vendors sold vegetables and fruits on the ground. These, all covered with dirt and dust, were bought and eaten without washing (Elliott 187). People showed little care about the cleanliness of their surroundings.

Manila was densely populated and had no building restrictions. People built structures whose firewalls leaned against each other. Throughout the city and its suburbs, houses were built crammed against each other; one had to slog through whole neighborhoods just to get to an intended address. Little was done to avoid the outbreak of diseases in these crowded conditions. As a result, many children died before they could even reach their first birthday (Elliott 187-89). What made things worse was that medicine in Manila was not very accessible. There was, for example, a high demand for quinine and yet actual supplies were severely limited. The people also did not understand the causes of certain diseases (Elliott 187). Despite all this, people endured the health risks just to carry out their duties and functions in the colonial center.

\section{City Transportation and Communication}

Intramuros and its suburbs were already suffering from heavy traffic at the beginning of the $20^{\text {th }}$ century. The inhabitants of Manila employed different modes of transportation: aside from the common horse-drawn vehicles, people also began using bicycles by 1889 (Agoncillo 90), and had access to 
a public transport system of streetcars. The Compania de los Tranvias de Filipinas was established by Jacobo Zobel de Zangroniz and Adolfo Bayo in 1885, but it only had five streetcars or tranvia service lines by 1892. These connected Manila and its suburbs, servicing Intramuros, Malate, Sampaloc, Tondo, Binondo and Malabon (Agoncillo 89).

Despite the public transport system, traffic in and out of Old Manila remained congested; it even turned worse through the years as the number of vehicles increased. By the 1880s, the Puente de España or Bridge of Spain that linked Intramuros and Binondo had 6,000 vehicles crossing it on a daily basis (Agoncillo 90). The Puente Colgante (now known as Quezon Bridge) was built to decongest traffic in the suburbs of Arroceros and Quiapo, with two lanes for carriages. However, a toll fee was charged on those crossing the bridge. ${ }^{6}$ By the turn of the century, five different kinds of horse-drawn vehicles could be found in Manila. These were the periles (de luxe carriages), araña (one-horse), victoria (two-horses), calesa, and the carretela (Agoncillo 89). There was no established, organized public transportation system that traversed the entire city and surrounding areas.

Manila could not easily leave its medieval identity behind. It took a long time before modern means of transportation were introduced to the populace; there also were no links to the neighboring cities and provinces. There was only one railway line in the archipelago, the Ferrocarril de Manila, which operated from Manila to Dagupan, Pangasinan. ${ }^{7}$ Moreover, few ships arrived from different parts of the world: Manila obviously was not well known to international shipping. Ships sailed from Manila to Hong Kong only once a week, while a ship bound for Barcelona set sail only once a month. Ships from Japan, the United States, Europe, and other parts of Asia arrived only intermittently, but it was only in 1891 that the Japanese Nippon Yusen Kaisha (NYK) started a regular route between Manila and Yokohama (Agoncillo 90). Manila had a long way to go in terms of modernization and urban development.

${ }^{6}$ The Puente Colgante was the first suspension bridge in the Far East, designed by the famed French Gustave Eiffel. Each person was charged one kusing or half a centavo, and for each horse, 2 centavos. Carriage toll depended on the number of wheels of said vehicle. (Agoncillo 89)

${ }^{7}$ The railway line stretched 120 miles from Manila to Dagupan, Pangasinan. It was constructed mainly by Filipino labor. (Agoncillo 89) 
There were also attempts around this time to develop the city and connect it to the rest of the world. In 1882, the Manila-Hong Kong overseas telegram cable was laid via Cape Bolinao in Pangasinan. This enabled Manila to communicate faster with the rest of Asia, Europe and various other parts of the world. Fifteen years later, the Eastern Extension Australia and the China Telegraph Company laid the first inter-island submarine cable linking Manila to Iloilo, Bacolod, and Cebu. In 1890, telephone service began in Manila though it only served 170 clients. ${ }^{8}$ But most of these advancements in communications only favored those who could afford them.

These facilities benefited the colonial government and the influential upper strata of society. Many Filipinos still relied on crude agricultural means for livelihood. Old Manila still lacked efficient means for development.

The most obvious and pressing need for this extensive urban development was electricity. Manila, though it was the center for colonial governance in the Philippine archipelago, was, by 1900, still a dark and dangerous place. There was yet no stable and regular electricity service from an established utility firm. Previously, in the early part of the $19^{\text {th }}$ century, Manila and its suburbs were partially lighted using coconut oil. The first streets to be illuminated thus were the residential areas of the European and Filipino elite, namely in the districts of Santa Cruz, Binondo, Quiapo, San Miguel and Sampaloc. By the 1880s, kerosene gas was also used (Agoncillo 90-1). By 1900, many homes still relied on burners for lighting at night. There were attempts at providing general electric service: a small electrical firm, La Electricista de Manila, was founded in 1893 (Agoncillo 91). But even then, only the streets and houses of the Manila elite for the most part had access to this service. It was still a dark, frightening city at night. To make matters worse, gas lamps were domestic fire hazards, especially to common Filipinos living inside nipa houses (Agoncillo 90). Definitely, there was a need to develop the medieval city at an accelerated rate if it were to improve its own quality of living.

${ }^{8}$ These clients included the Manila Archbishop and the Spanish governor-general. The telephone company had its main office inside Intramuros with a branch in Calle Jacinto (present $T$. Pinpin) in Binondo. (Agoncillo 90) 
Jason A. de las Alas, "Medieval Manila: Life at the Dawn of the 20th Century"

\section{Conclusion}

At the beginning of the $20^{\text {th }}$ century, Manila was still medieval in character, as it originally had been laid out by the Spanish. Though living conditions inside the walls of the city were crude and congested, life in Manila still thrived. The city served as the center for administration and culture of the colony.

Through innovative house design and construction, the inhabitants of Manila adjusted to the climate and evidently adverse conditions inside the city. But life in Manila was also centered inside the home and upon each one's family. People tried their best to enjoy life inside the Spanish city, despite it not being an exact replica of a European city. But a new colonial ruler was about to enter and change the culture and way of life for the medieval city. Manila was at a crossroads, caught between its past and the approaching modern era.

\section{Works Cited}

Agoncillo, Teodoro A. History of the Filipino People. $8^{\text {th }}$ ed. Quezon City: R.P. Garcia, 1990. Print.

Chandler, David, et al. The Emergence of Modern Southeast Asia: A New History. Ed. Norman

G. Owen. Honolulu: University of Hawaii Press, 2005. Print.

Elliott, Charles Burke. The Philippines: To the End of the Commission Government. New York: Greenwood, 1968. Print.

Foreman, John. The Philippine Islands. New York: Scribner Book, 1906. Reprinted by Cacho Hermanos, Manila, 1985. Print.

Hahn, Emily. The Islands: America's Imperial Adventure in the Philippines. New York: Coward, McCann \& Geoghegan, 1981. Print.

Hamm, Margherita Arlina. Manila and the Philippines. London: F. Tennyson Neely, 1898. Print.

Howard, Charles B. "Life in Manila." In The Philippines. Boston: Perry Mason, 1900. Print. Javellana, Rene B.. Intramuros: In and Around. Quezon City: Jesuit Communications, 2003. Print.

Laya, Jaime C. and Esperanza B. Gatbonton, eds. Intramuros of Memory. Manila: Intramuros Administration, 1983.Print.

MacMicking, Robert. Recollections of Manila and the Philippines. Ed. Morton J. Netzorg. Manila: Filipiniana Book Guild, 1967. Print.

Nicholas, David. Urban Europe, 1100-1700. New York: Palgrave Macmillan, 2003. Print. 
Patanñe, E.P. "Manila: A Cultural Geography." Intramuros and Beyond. Manila: Letran College, 1975. Print.

Pounds, Norman. The Medieval City. Connecticut, Mass.: Greenwood, 2005. Print.

Sta. Maria, Felice Prudente. "Leisure Time in Old Manila." Kasaysayan: The Story of the Filipino People. Vol. 4. Hong Kong: Asia Publishing Co. Ltd., 1998. Print.

Torres, Jose Victor Z. Ciudad Murada. Manila: Intramuros Administration and Vibal, 2005. Print.

Zialcita, Fernando N. and Manuel I. Tinio, Jr. Philippine Ancestral Houses, 1810-1930. Quezon City: GCF Books, 1980. Print.

Jason A. de las Alas graduated with an AB in History from the Ateneo de Manila University in 2008. He is presently an MA candidate, majoring in Education in the same university. He taught Social Studies and Filipino at the Ateneo de Manila University Grade School for one year, and is currently a social studies faculty member of Miriam College High School. His research interests are primarily divided between history, education, migration studies. 